\title{
GROWTH OF A WESTERN TARAI DISTRICT HEADQUARTER: A CASE OF PARASI BAZAR FROM 1978 TO 1996
}

\begin{abstract}
Ashok Rajbanshi
\section{INTRODUCTION}

The contemporary Rana government of Nepal began to deforest the southern Tarai region for the purpose of exporting timber and foodgrain after the colonial British government of India constructed railways upto the southern border of Nepal. Because the Sal timber and the foodgrain produced in Tarai region could be exported to India by the means of cheap railway transportation and sold there for a good price. A large portion of profit earned by this timber and foodgrain trade was gone to the treasures of Rana rulers. But the remaining portion of the profit was used to import various industrial manufactured goods. (Lohany; 1970) In this way trade developed and central Tarai. Those cities became the center of attraction for many traders and foodgrain producing farmers. And people began to migrate here from nearby areas of India and to the But the hill people of Nepal did not want to migrate there for economic gain due to the fear of malaria epidemic. Majority of migrants came to settle in Tarai only after in Nepal. But unforaria in the sixties. Since 1956, planned economy was introduced and central Tarai and region lagged behind in programme launched by WHO area of economic opportunities spread aID, information about Tarai as a whole, as an in the hills and in parts of the Gangetic the hill villages. Economic deterioration positive factors in the form of economic plain has necessitated out migration, and the Tarai. The result is a continued immig opportunities have encouraged migration into for acquiring land or trying a new set of igration of households and individuals to Tarai
\end{abstract}

After the declaration of national referendum in 1979 a large number of Indians residing in Tarai region of Nepal were given Nepalese citizenship by government authorities. Moreover friends and relatives of Indian citizens, living in Tarai region of Nepal encourage Indians to immigrate into Tarai area of Nepal. Consequently Tarai region of Nepal is becoming the destination place for migrants from both north and headquarters settlements of Tarai belt are growing very rapidly. All the Tarai district of Bardiya, western administrative and marai) and Parasi. Actually Parasi Bazar acts only as a district lack of development of centre for surrounding agricultural hinterland. Due to the lack of development of appropriate socio-economic infrastructures and unfavorable 


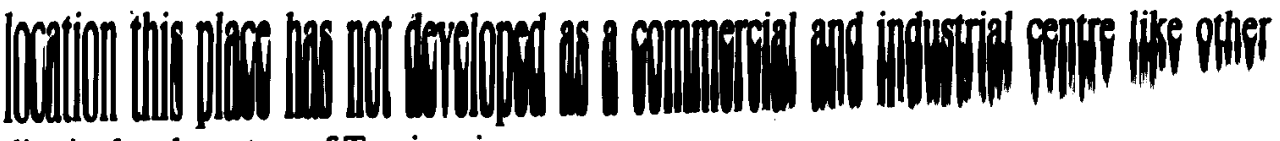

district headquarters of Tarai region.

\section{LOCATION OF PARASI BAZAR}

Parasi Bazar is located on the western bank of Jharai river at Parasi Village Development Committee (V.D.C.) in western part of Nawalparasi district, Lumbini Zone (Appendix Fig.1). Parasi is the district headquarter of Nawalparasi district, a southern district of western development region. Nawalparasi district is surrounded by Chitawan district in the east, Tanahun in the north, Palpa and Rupandehi in the west and the Indian province of U.P. in the south. Geographically Nawalparasi can be divided into three regions- hill, inner Tarai and tarai. Parasi V.D.C. is situated in the tarai region of this district. Situated at an altitude of 152 meters above the mean sea level, Parasi Bazar is located 9 kilometers southward from Sunawal (a east-west highway market centre) and $22.5 \mathrm{kms}$. eastward from Bhairahawa. In ancient times this place was called Pali Majhkhand- from Rana period this was an administrative centre for Nawalaparasi district. In 1976 Sunawal-Parasi road was constructed and electricity distributed. Since then the market area has developed very slowly, although the population of market area has increased by about 80 percent within a time span of 20 years (from 1975-76 to 1995-96). Southern part of Nawalaparasi district is divided into eastern and western parts by Daunne hill, a spur of Churia range. The eastern part is called Nawalpur and the western part Parasi. Nawalapur is close to Bharatpur municipality and Parasi region is close to Butwal and Siddharthanagar municipalities. So the spheres of influence of this Parasi Bazar is Limited.

\section{OBJECTIVES OF THE STUDY}

The specific objectives of this study are as following:

1. To find out the number and origin of migrants and the growth of population;

2. To find out the growth in the number and types of functional units; and

3. To find out the change in landuse pattern in Parasi Bazar from 1978 to 1996.

\section{METHODOLOGY}

This study is mainly based on primary data and information collected by field survey. The data related to migrant population and households' numbers and their place of origin were collected by interviewing all the households in the market area of the V.D.C. with the help of a questionnaire form prepared beforehand. And only those households whose head had inmigrated himself was considered migrant households. Out of the total houses (922) of the market area only 590 houses (64 percent) were visited for interviewing. It was assumed that only one household or family lived in a 
house, taking the owner of the house as the respondent for interview. The recent wardwise population size and number of houses were collected from the local V.D.C. office. These statistics for the years 1971 and 1975-76 were collected from the available secondary sources. The number of different shops and services and industries were recorded in observation forms, filled during two different periods of the field visits, i.e. in 1978 and in 1996. The existing landuse pattern was derived from the aerial photography of 1992 as well as by field observation. The previous landuse pattern of the market area in 1978 was derived from the aerial photo of 1978 and the field observation.

\section{LIMITATIONS OF THE STUDY}

All the households could not be interviewed due to the absence of respondents during the researcher's visit and households located far from the main market area could not be visited due to time constraint. It is a very surprising fact that none of the migrants told that they were from India. Wardwise population size of the year 1978 or other times could not be acquired except for the year 1994. And the total population of the market area of the year 1978 was also not available.

\section{POPULATION GROWTH IN THE MARKET AREA}

According to the census of 1971, Parasi village panchayat had a population of 3196 and there were 175 houses in Parasi market area. Parts of ward numbers 4, 5, 6 and 8 of Parasi village panchayat formed Parasi Bazar (market area). Major portion of market area was located in ward number 8 . Ward number 5 is the oldest settlement area of this market. In 1975-76, the total population and house units of Parasi market area was estimated to be about 3000 and 190. respectively. (Bhandari; 1975) In 1995-96 the total population of Parasi V.D.C. reached 7532. Among them 5408 lived in market area which includes parts of ward numbers $4,5,6,7,8$ and 9 of the V.D.C. (Table: 1). The major portion of market area now lies in the ward numbers 8 and 6 . In 1995-96, the total number of houses area was 922 (Table: 1). This reveals that the population size in the Parasi market area has increased by 80 percent from 1975-76 to 1995-96. Out of the total population of this V.D.C. about 72 percent live in market area. And the ethnic composition of the households of Parasi market area shows the fact that this is the destination place for migrants from both north (hills) and south (plains) from the earlier times (Table: 2). 
Table 1;. Wardwise population and house number in Parasi V.D.C.

\begin{tabular}{|c|l|c|c|}
\hline Ward No. & Name of settlement & Population & No. of Houses \\
\hline 1 & Sanda & 323 & 38 \\
\hline 2 & Sanda & 391 & 54 \\
\hline 3 & Sahubatika & 633 & 99 \\
\hline $4^{*}$ & Parasi & 932 & 159 \\
\hline $5^{*}$ & Parasi & 678 & 102 \\
\hline 6 & Ghodapali & 507 & 62 \\
\hline $6^{*}$ & Parasi & 971 & 145 \\
\hline $7^{*}$ & Parasi & 189 & 114 \\
\hline 7 & Kerawani & 135 & 19 \\
\hline 7 & Kuryapura & 135 & 19 \\
\hline $8^{*}$ & Parasi & 1315 & 223 \\
\hline $9^{*}$ & Pokharapali & 1323 & 179 \\
\hline & Total & 7532 & 1213 \\
\hline
\end{tabular}

Source: Parasi V.D.C., 1996.

*Ward numbers of the market area.

Table 2:- Ethnicity by households at Parasi market area

\begin{tabular}{|l|c|}
\hline \multicolumn{1}{|c|}{ Ethnicity } & Number of households \\
\hline Tarai castes & 301 \\
\hline Tharu & 17 \\
\hline Occupational castes & 78 \\
\hline Hill Brahmin & 86 \\
\hline Newar & 28 \\
\hline Chhetriya & 45 \\
\hline Magar & 5 \\
\hline Gurung & 2 \\
\hline Others & 28 \\
\hline Total & 590 \\
\hline
\end{tabular}

Source: Field survey, 1996

Tarai castes include Madwari, Yadav, Lohiya, Bhar, Tarai Brahmins, Muslims, Kaliraj, Baniya, Dhuniya, Jayasawal, Gunta, Sahu, Haluwai etc. ethnic groups. Similarly Teli, Kohar, Damai, Dhobi, Harijan, Thakur, Pasi, Kewat, Chamar ethnic groups belong to Occupational castes. Generally the majority of migrants from the hills are high caste people where as the majority of Plains migrants are of low caste. (Gaige; 1975) 


\section{NUMBER AND ORIGIN OF MIGRANTS IN THE MARKET AREA}

Out of the total households interviewed, only 110 were migrants and the remaining 480 were local. Most of the migrants had immigrated after the year 1984 (Table: 3).

Table 3: Year of migration

\begin{tabular}{|c|c|c|}
\hline Year & No. of households & Percentage \\
\hline Before 1974 & 8 & 7.3 \\
\hline $1974-1983$ & 28 & 25.5 \\
\hline $1983-1993$ & 60 & 54.5 \\
\hline After 1993 & 14 & 12.7 \\
\hline Total & 100 & 100.0 \\
\hline
\end{tabular}

Source: Field survey, 1996. given below.

The number of households, migrant population and their place of origin are

Table 4: Year of migration

\begin{tabular}{|l|c|c|}
\hline \multicolumn{1}{|c|}{ Place of origin } & Na. of houscholds & Population \\
\hline $\begin{array}{l}\text { Villages within Nawalparasi } \\
\text { district }\end{array}$ & 58 & 204 \\
\hline Other Tarai districts & 27 & 72 \\
\hline Hill and Mountain districts & 25 & 92 \\
\hline Total & 110 & 368 \\
\hline
\end{tabular}

Source: Field survey, 1996.

The northern part of Nawalparasi district is mountainous in topography. So the land hungry people from these mountainous areas are migrating to this Tarai district headquarter. Similarly the migrants' number from neighbouring villages of Unwach, Ramnagar, Jamuniya, Swathi, Banjhariya, Hukai, Sukrauli etc. are also large. Thus out of the total migrant population 55.4 percent have migrated from within the Nawalaparasi district for various reasons.

Rupandehi is the major origin of migrants from other Tarai districts. 22 households comprising 58 people have migrated to Parasi Bazar from Rupandehi. Migrants from other Tarai districts- Kailali, Taulihawa, Chitawan, and Rautahat are 
The hill and mountain district immigrants belong to the districts of Palpa Parbat, Baitadi, Gulmí, Jumla, Syangja, Kask, Tanahun, Arghakahanchi and Kathmandu. Among them the largest number of households and population immigrated are from Palpa. 6 households comprising of 27 people have migrated to Parasi from Palpa district.

\section{GROWTH IN THE NUMBER AND TYPES OF FUNCTIONAL UNITS (SHOPS AND SERVICES) IN THE MARKET AREA}

The total number of shops and services have nearly doubled in 1996 from that of the year 1978 (Table: 5). This table shows that the number of Kirana retail shops reached 43 in 1996 while they were only 22 in 1978 . The other mentionable growth are found in the number of agricultural tools and repairing shops. The number of repairing shops, which includes cycle and motorcycle repair, machinery, tyre repair, watch, T.V. and radio repair, increased by five times, while the agricultural tools shops increased by more than three times from 1978 to 1996. In 1996 survey the catering services were found to number of small tea stalls and establishment of modern restaurants in recent times conforms this. Another remarkable aspect is the rising trend in the number of traditional industries such as rice, oil, flour and saw mills. Besides the traditional industries some new types of industries such as grill manufacturing, loaf making, beaten rice making have also been found to be established in Parasi market area in 1996. New types of shops and services were also found in this market. Such units were absent during the survey conducted in 1978. Table 6 shows the list of such new functional establishments found during the field survey in 1996. A total of 84 new functional units have been established in Parasi market area. Among them fancy goods and cosmetics shops, Bhatti, hair cutting shops and law firms are worth mentioning. Some financial institutions like agricultural development Bank, commercial bank- one each and three cooperatives and two agricultural extension service offices were also found in the market area. 
Table 5: Number and types of shops and services in Parasi market area

\begin{tabular}{|l|c|c|}
\hline \multicolumn{1}{|c|}{ Types } & Number in 1978 & Number in 1996 \\
\hline Retail kirana & 22 & 43 \\
\hline Small tea shops & 21 & 11 \\
\hline Hotel and lodge & 9 & 11 \\
\hline Modern restaurants & - & 6 \\
\hline Stationery, books & 3 & 19 \\
\hline Tailoring & 15 & 14 \\
\hline Clothes & 10 & 12 \\
\hline Pharmacy & 6 & 7 \\
\hline Vegetables and fruits & 2 & 7 \\
\hline Agricultural tools & 2 & 3 \\
\hline Petrol, diesel, Kerosene & 1 & 55 \\
\hline Repairing shops & 11 & 1 \\
\hline Shoe repairing shop & 1 & 5 \\
\hline Photography & 2 & 8 \\
\hline Hardware & 2 & 3 \\
\hline Godown & 12 & 36 \\
\hline Industries & 17 & 22 \\
\hline Others (cold store etc.) & & 6 \\
\hline Total & 25 & 6 \\
\hline
\end{tabular}

Source: Field survey, 1997 and 1996. 


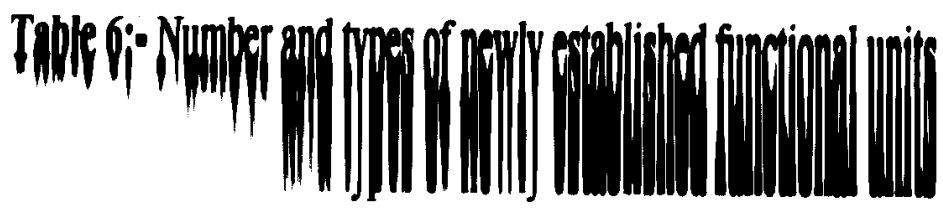

\begin{tabular}{|l|c|}
\hline Types of shops and services (functional units) & Number \\
\hline Meat & 4 \\
\hline Grains (wholesale) & 4 \\
\hline Footware & 2 \\
\hline Fancy goods and cosmetics & 15 \\
\hline Electric goods & 6 \\
\hline Readymade garments & 2 \\
\hline Metal utensils & 2 \\
\hline Bhatti & 8 \\
\hline Hair cutting & 10 \\
\hline Washerman & 1 \\
\hline Law firm & 10 \\
\hline Goldsmith & 7 \\
\hline Photocopy & 2 \\
\hline Art/painting & 1 \\
\hline Spectacles & 2 \\
\hline Cinema hall & 1 \\
\hline Printing press & 4 \\
\hline Eye clinic & 1 \\
\hline Ayurvedic clinic & 1 \\
\hline Family planning clinic & 1 \\
\hline Total & 84 \\
\hline
\end{tabular}

Source: Field survey, 1996.

\section{CHANGE IN LAND USE PATTERN}

Although Parasi is the district headquarter, it is still a small market center with rural landscape. The built up area is limited and it is prominently succeeded by agricultural uses which occuupies extensive part of this market area. Agriculture use is nowhere constrained by physical barrier. The major changes in areas of landuse category of Parasi has been given in the following table (Fig. 2 and 3). Only 31.5 hectares of agricultural land has been converted to mainly built up area within the last eighteen years from 1978 to 1996 . During that period the built up area has been expanded mainly towards north along the Parasi-Sunawal road and west along the Parasi-Bhairahwa road. Institutional landuse has not developed so far. Mixed landuse is the dominant feature in the built up area. This mixed character is seen in different types of land use categories including residential, commercial, institutional, administrative and industrial. It is to be noted that even one storied houses are used in a 
mixed way-commercial, residential. In several other houses, ground floor is used for either shops or industry or institutions and administrative office. Upper floors in these houses are occupied by residential uses. Out of the 590 houses only 374 units are used extensively for residential purposes.

Table: 7: Change in land use pattern (1975-1996)

\begin{tabular}{|l|c|c|c|c|}
\hline \multicolumn{1}{|c|}{ Landuse category } & $\begin{array}{c}\text { Approximate } \\
\text { area in hec. } \\
\text { in 1978 }\end{array}$ & Percent & $\begin{array}{c}\text { Approximate } \\
\text { area in hec. } \\
\text { in 1996 }\end{array}$ & Percent \\
\hline Agriculture & 288.5 & 51.6 & 257 & 46.0 \\
\hline Grassland, bushes \& wasteland & 129.0 & 23.0 & 120 & 21.4 \\
\hline Build up area & 13.5 & 2.4 & 52 & 9.3 \\
\hline Road \& trails & 48.0 & 8.6 & 50 & 8.9 \\
\hline River \& water bodies & 41.0 & 7.3 & 41 & 7.3 \\
\hline Orchards \& forest & 40.0 & 7.1 & 40 & 7.1 \\
\hline \multicolumn{1}{|c|}{ Total } & 560.0 & 100.0 & 560.0 & 100.0 \\
\hline
\end{tabular}

Source: Air photographs 1978 and 1992 and field work 1996.

The area covered by road and trails has increased by only 2 hectares within the last eighteen years from 1978 to 1996 . During this period the amount of grassland and wasteland areas mainly on the banks of Jharai river has decreased by 9 hectares, majority of which has been turned into forest and some of them have been covered by residential and cultivated areas. The forest area in other parts of Parasi, Mainly in ward number 9 and 3, has decreased considerably. On the whole the land use pattern of Parasi Bazar clearly shows the initial stage of urban land use evolution.

\section{CONCLUSION}

As a district headquarter, Parasi Bazar contains many government, non government offices, communication facilities, financial and social institutions like banks, cooperatives, schools, hospital, clinics etc. Currently an old 25 bed hospital at Parasi, is serving the people of Parasi and surrounding areas. But this hospital lacks required number of doctors and other technical man power. A vocational or technical college related to agriculture and animal husbandry is necessary to open here as soon as possible. Other physical facilities which are urgently needed in the market area are construction of sewerage and drainage lines, metalled roads and proper management of solid wastes and dirt. Lumbini sugar mill at Sunawal is using Jharai river, which flows through the eastern side of Parasi, as a dumping site for the polluted waste materials produced in the factory. This causes harmful effect to the aquatic lives of the river and other environmental pollutions. So these activities must be checked in time. 


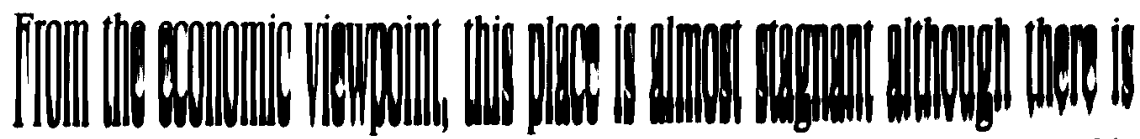

some increase in the number of functional units and industries from 1978 to 1996 . This is mainly due to its isolated location without any facilities or institutions to attract the people from the surrounding areas. People from northern hill region and within Nawalaparasi district visit either Butwal, Bhairaahwa or Narayanaghat for commercial purposes. To attract them towards Parasi Bazar and increase peoples' mobility here construction of a motorable road from Tribeni to Bhairahwa through Harakatuwa and Parasi is very important. There is a Budhist archaeological site at Ramgram, 4 kilometers southeast of Parasi market. Ramgram is a popular place for Budhdist tourists because of the preservation of relic of Lord Budha. Tourists visiting Lumbini certainly wish to see Ramgram if necessary infrastructures and other facilities are provided. No doubt, this will make a positive impact in the development of Parasi Bazar. Local -efforts and peoples' participation is the most to achieve the above goals. Finally it is high time for political parties to think seriously whether they like to develop their concerning areas by proper and optimum utilisation of available resources or use people irrationally as votebanks only.

\section{ACKNOWLEDGEMENTS}

The author wishes to express his deep gratitude to Department of Geography and Psychology, Tri-Chandra Multiple Campus, Kathmandu and Central Department of Geography, T.U, Kirtipur for providing necessary support and guidance during the field surveys conducted in 1978 and 1996 respectively. He also gratefully acknowledge the assistance given to him by Mr. Kedar Dahal and the local people of Parasi market area. 


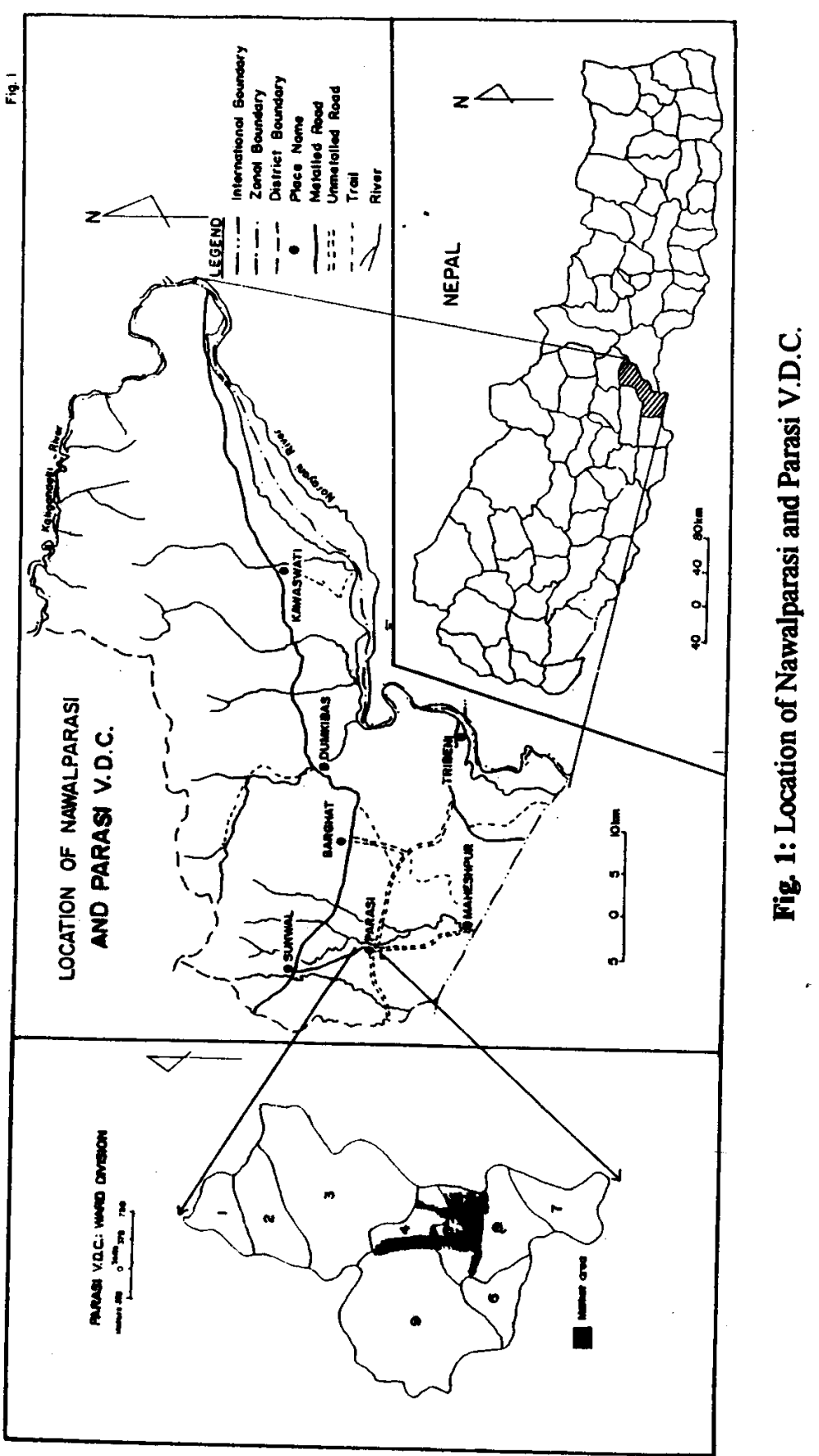




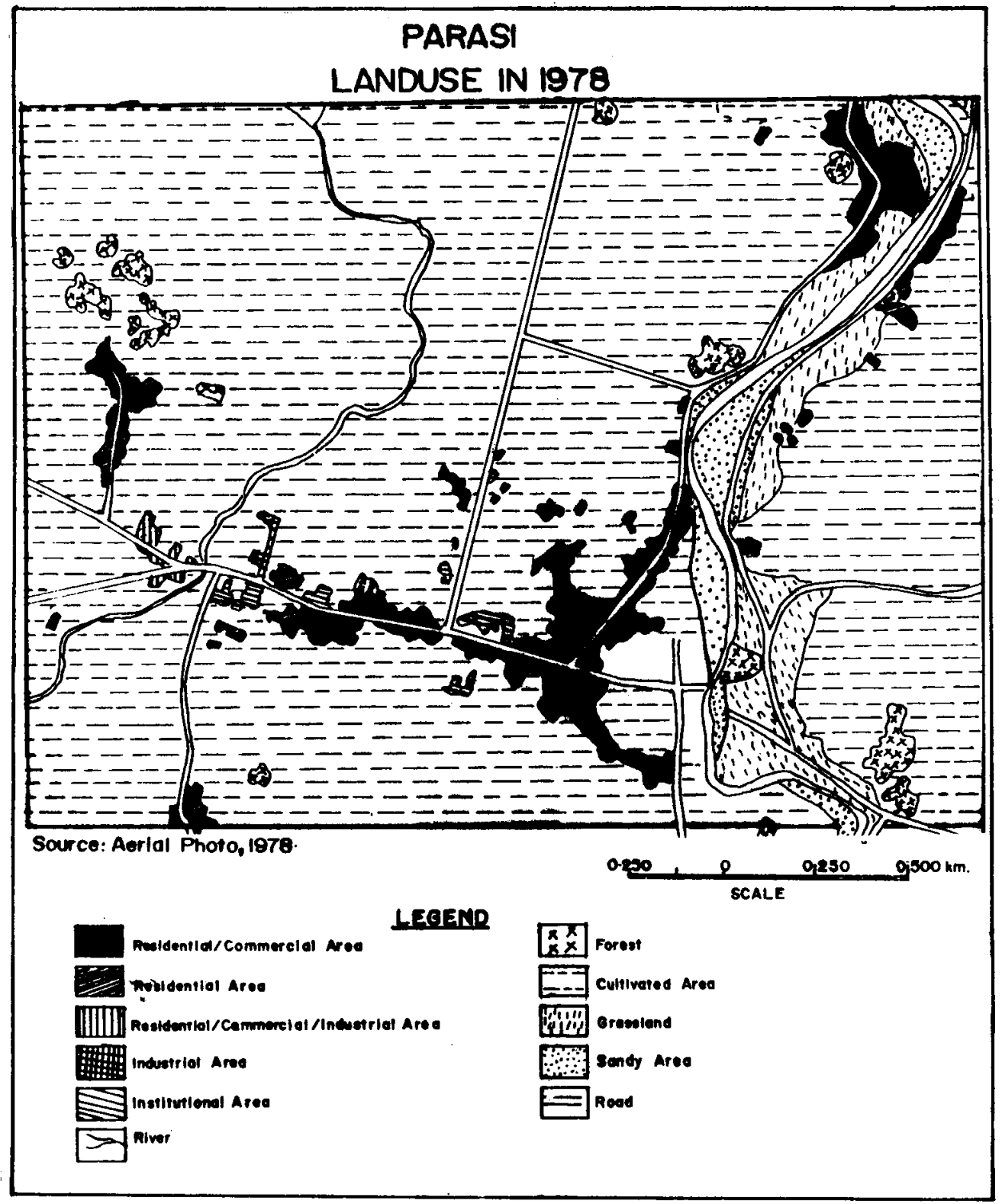

Fig. 2: Parasi landuse in 1978. 


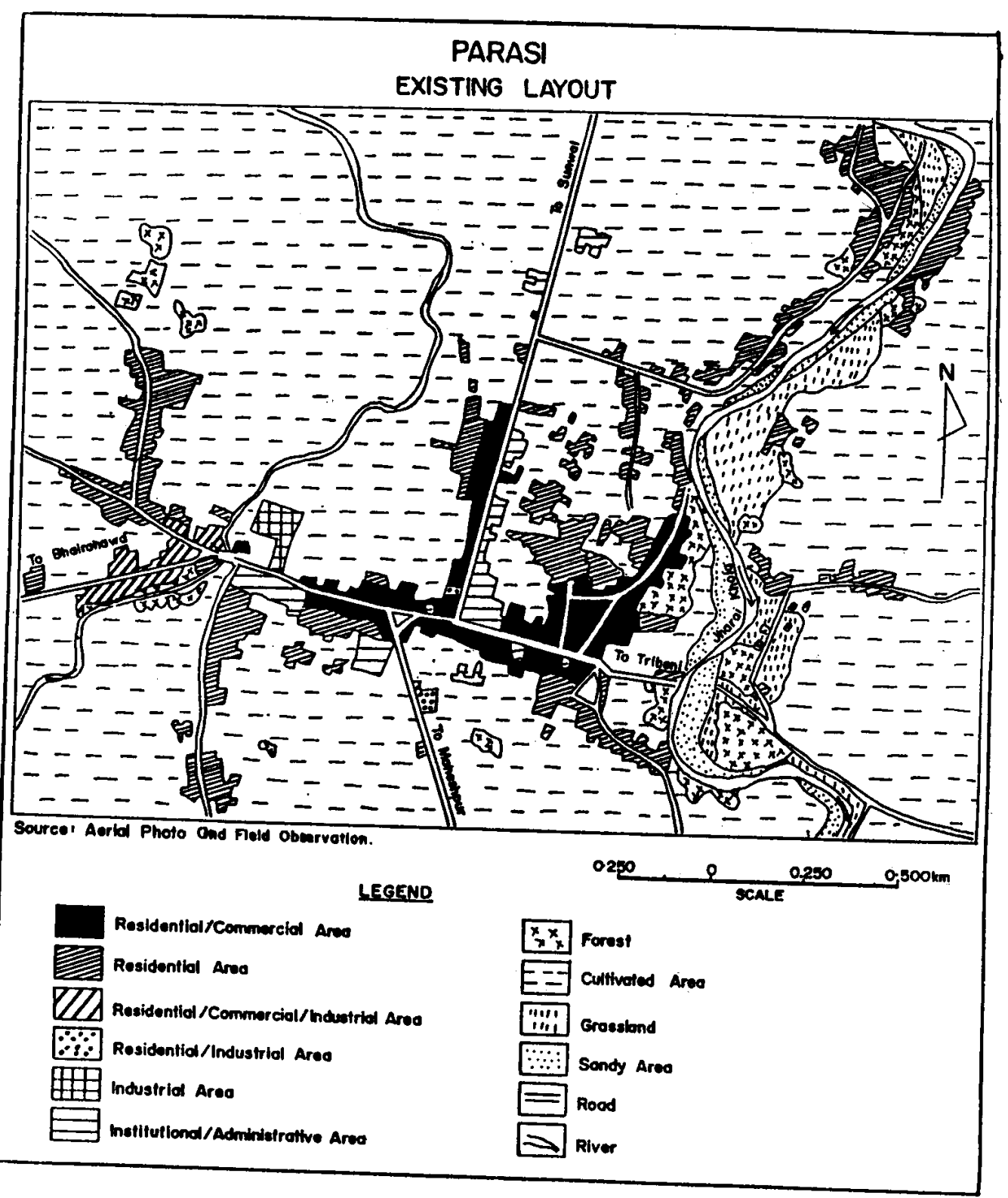

Fig. 3: Parasi existing layout. 
Bhandari, Kanak R., (1975-76), "Parasi Village Panchayat: Local Agricultural Productivity and Its Uplfiftment," unpublished village profile, submitted to Inst. of Hum. \& Social Science, T.U.

Gaige, Frederick H., (1975), Regionalism and National Unity in Nepal, University of California Press, Berkley, p. 74.

K.C., Bal K., (1983), "Consequences of Rural to Rural Migration in Nepal"- paper presented in International Symposium on Mountain Population Pressure, Kathmandu, p. 7 .

Lohany, P.C., (1970), "Nepalko Audyogik Sthiti"- paper presented in Easiern Industrial Conference held at Biratnagar, p. 2. 